\title{
THE RELATIONSHIP BETWEEN MIGRATION AND POVERTY
}

\author{
H.L. Hansi Apsara \\ Department of Sociology, University of Ruhuna, Sri Lanka
}

\begin{abstract}
Sri Lanka and as result not only men but also women who became the breadwinner of a family. The women or men, who live in rural areas and fell in poverty, select migration as the oldest action against poverty. The sample survey was conducted in Sri Lanka from August to December 2017, covering 80 females who were worked so domestic human resources abroad. The study explore the bond sandwiched between the poverty furthermore the migration of the special analysis area in Sri Lanka. Sri Lanka has paid attention to overcome the problem of poverty since her independence, but still there are considerable amount of the population living below the national poverty line. Also relevant data for the study were gathered from the secondary as well as primary sources. The main primary data collection methods were questionnaire survey, household interviews and key informant interviews. The present situation of the village is a result of number of factors which directly or indirectly affect the women's and men's economy in Sri Lanka. The study found that the main reason for their poverty situation is low income regarding the lack of educational attainment of the women have negatively affected their present living standard. And also most of the women reported that present poverty alleviation program (Samurdhi) isn't enough to overcome the poverty situation. Other reasons for women's migration were image the relationship of present poverty situation in the area, lost some valuable opportunities for their education due to poor condition of their families, thinking much about their children and fulfill their requirements than others requirements of the households' etc. It seems that there is no good guidance for the poor people of the area. As many of the people in the village have the negative ideas about their poverty situation, there should be stronger guidance for the people. Without such a strengthening of the people it is difficult to upgrade peoples' living standard. If there is awareness programs and if give some kinds of training and self-employment programs, it will be helpful to overcome their poverty conditions and not to get decision to migrate.
\end{abstract}

Keywords: migration, women, poverty, Sri Lanka

\section{Introduction}

A violation of human rights and a denial of the most basic needs of the poor could be regarded as poverty in developing countries. Poverty is a major socio-political issue in Sri Lanka. It was recognized as a critical issue in the late 1980's and a limited poverty alleviation programme of income support was introduced in 1989, but the incidence of poverty still exists. This is partly a reflation of growing income and other disparities in the country and partly a result of the deterioration of publicly provided services such as health, education, environmental sanitation and transport. Increasing private investments in some of these areas have been accompanied by a decline or at least a stagnation of public investment. The result is that higher income groups have access to high quality services in the private sector while low income people who constitute the vast majority of the population are compelled to rely on deteriorating health, education and transport services. Moreover, even the poor cannot rely entirely on publicly provided services as they are forced to pay for some of the services such as prescription drugs, medical tests, private tuition, school transport, etc. For all these, they have to use their meager earnings. This situation makes it virtually impossible for the poor to satisfy the basic needs of their household members, forcing them deeper into poverty and indebtedness. This largely explains the 
continuing exodus of low-income persons from rural and plantation areas. Consequently, population pressure is increasing in cities and towns throughout the country leading to urban social problems.

Poor relief by way of cash transfers hardly provides an adequate cover against income and consumption poverty. The amounts involved are insignificant. For instance, most poor families receive the equivalent of anything between Rs. 500 to Rs. 1000 a month barely enough to buy a kilogram of imported powdered milk. Increasing costs of food, health care, education, housing and transportation compel people to look for higher incomes outside the country. Though overseas employment provides higher incomes, it does not ensure long-term social security. As is well known, people employed abroad on short-term contracts are not covered by social security systems like pensions and retirement gratuities, either at home or abroad. Unless they invest part of their income in long term savings bondsetc., their future is likely to be as uncertain and instable as their present situation. As is evident from research, most short-term migrants use up their earnings for day-to-day requirements at home and often have no savings or investments to fall back on when they can no longer work due to age or other constraints.

When we discuss on women migration in the context of poverty reduction, out of the 190 million migrants in the world today, almost 50\% are females; many of them moved from and within developing countries. More than 166 billion in 2014, migrant remittances sent home to developing countries, it is noticed that major proportion was received by women. Migration, particularly through remittances, can be an important factor for poverty reduction and growth in many developing countries like Sri Lanka (Lucas, 2004; Adams, 2005).

\section{Statement of the Research Problem}

Why do huge numbers of Sri Lanka women migrate overseas despite their family commitments? Various types of factors at origin and destination, as well as individual reasons, household and country level factors (Ghosh 2009; Eversole 2006) determine their migration. These migrant women come from low-income families and have lower levels of education, which inhibits their possibilities of entering into the local labour market. Even if they are employed in Sri Lanka, their salaries are low, and their families' lives in poverty. They need more money to improve the economic and social well-being of their families. Since they couldn't find other alternatives to earn money in Sri Lanka, they take the decision to migrate. Therefore, the main reason for their migration is mainly economic. These economic reasons consist poverty, limited employment opportunities for them to work in Sri Lanka, unavailability of permanent jobs for their husbands, repayment of debts, buying a land, building a house, and family obligations. Poverty alleviation and building a house were expressed as the main reasons for migration by an equal proportion of migrant families (about 36 per cent). Among the noneconomic reasons such as providing better education and health for their children and recovering husband's illness were reported as main reasons only by a small proportion of families. Although the provision of education for their children was the main reason for migration only for a small number of families, it is one of the reasons reported by more than half of the families.

Economic development causes to increase female labour force participation, limited time that women can spend on household chores and childcare activities, and government policies of destinations countries in the Middle East and Southeast Asia has generated a demand for Sri Lankan migrant workers (Ghosh 2009; SLBFE 2009; Hugo 2005b; Asis 2004a; Chammartin 2004a; Lim and Abella 1994). Moreover, advancements in transportation and communication technologies that link places and people globally, easy access to information in finding job opportunities, quick communication with family members, and immediate transfers of remittances made it easy for women to migrate internationally (Sumulong and Zhai 2008; Wickramasekera 2002). Who gets the decision to migrate? Person mainly responsible for the decision to work overseas is the migrant. The migrant woman is the people who have more power in taking the decision to migrate. Their migration is recognized as a household strategy since the reason for their migration generally for the improvement of the well-being of their families 
with reducing the poverty. The study mainly focused on; do the women's migration able to reduce their poverty situation of their family?

\section{Objectives of Study}

Sri Lanka has paid attention to overcome the problem of poverty since her independence, but still there are considerable amount of the population living below the national poverty line. The main objective of the research is to explore the ability of reducing poverty situation in their families regarding to the women's migration of the selected study area. The specific objectives are to identify how the remittances effect to reduce their poverty, to investigate the relationship between the poverty and the gender basic.

\section{Methodology}

The sample is motley in the sense that it included migrant households with different socio-economic characteristics. It consists of 80 returned females who were worked as domestic workers in abroad at the time of the survey. The sample survey was conducted in Sri Lanka from August to December 2017, covering 80 respondents with using judgment sampling. These types of migrant households were selected for the study assuming that the perception of the females on the impact of reducing poverty condition through women's migration to their families. Field Research Design is the main data collection method used in this study. Demographic and socio-economic characteristics such as age, ethnic group, number of children, marital status, educational attainment, income, occupation provides background information for this study. Both primary and secondary data were used for this study. Therefore, primary data required for this study had to be collected by means of a sample household survey using a structured questionnaire and In-depth Interview. Secondary data likewise the departures for foreign employment, occupational categories of migrants were collected from the published records of the SLBFE. In addition relevant data were also collected from the official Social and Economic reports and Department of Census and Statistics, the Central Bank of Sri Lanka and the Divisional Secretariat. A selective content analysis of media especially print media was also carried out to capture an understanding of how women migrants in the media were a focus of the study.

\section{Theoretical Background and Literature Review}

Gender as a social construction that organizes relations between males and females can greatly differentiate the causes, processes and impacts of migration between the two sexes. Knowing how these differences play out at the interface of migration and poverty can be important for achieving the third Millenium Development Goal to promote gender equality and empower women, as a way of enhancing economic growth and reducing poverty. A gender analysis of migration looks beyond simple differences in migration behaviour between men and women - such as the likelihood and type of migration - and examines the inequalities underlying those differences. It looks at how these are shaped by the social and cultural contexts of the individual, and the influence that membership of social groups and economic and political conditions can have on decisions about migration.

The household theory about migration decisions being taken rationally by families was an important departure from earlier neoclassical economic theories of migration. It recognizes that the relative control over resources exercised by men and women has a significant and often gender differentiated impact on family consumption and expenditure. But it has not adequately accounted for the fact that households, like workplaces, can be sites of inequitable decision- making in many cultures. Gender inequality can permeate the decision, process and impacts of migration, as well as the networks and support systems that play a key role at all stages of migration (UNGA, 2004). But migration can also help reconfigure gendered relations, particularly by offering more women the opportunity to enter the global labour market. 
Migration can result from poverty, but it is not always the poorest who migrate, because of the costs and opportunities involved (World Bank, 2005). And poverty may result from migration, both for the migrants in destination locations and the families left behind, often mostly affecting women and children. At the same time, female migration can indirectly help alleviate poverty by raising the productivity, education and health of the females and their families, all key to reducing inequality and poverty in the home.

But evidence of the positive impacts of migration on poverty remains scanty. Firstly, a number of developing countries with high poverty levels have no significant studies on migration, poverty and livelihoods (Black, 2004a), let alone gender analyses in that field. Secondly, most immigrant-receiving countries do not consider the gender implications of their immigration policies and programs, and thirdly most migration literature to date has been gender indifferent, or given it a male bias. Overarching this is a general deficit of evidence on the exact impact of migration and remittances on poverty.

The gender distribution among migrants today is reasonably balanced, with almost 50 percent of the global migrant population today being female, although the increase has been mainly in the developed world. Between 1970 and 2000 the numbers declined in Asia (46.6\% to 43.3\%) and North America (51.1\% to 50.3\%), but rose in Africa $42.7 \%$ to $46.7 \%$ ), Oceania (46.5\% to 50.5\%), Latin America and the Caribbean (46.8\% to 50.2\%) and Europe $(48 \%$ to $51 \%$ ). But these statistics on recorded migrant populations do not reveal the true numbers of movements, particularly within countries and regions. We do know that in most developing regions more females are migrating independently, i.e. not just as dependents or family members, and more are making a difference for development (Sorensen, 2004).

Our perception of international migration is that it was predominantly a male phenomenon during the large labour movements of the 60s and 70s in Europe and the US, with women and children following in secondary waves of family reunification in the 1980s and1990s. But by the 1990s, women were migrating in far higher numbers, both as family members and independently, voluntarily or involuntarily. This has certainly been the experience of Maghrebian women (particularly Moroccans) in the EU region (Khachani, 2001; Sorensen, 2004). In Asia and Africa, more women have become primary wage earners in domestic and cleaning jobs, child rearing, care of the elderly, and as nurses and hospital aides (UN World Survey, 1999).

Migration can help raise women and men from the lower to lower middle class socio-economic ranks (ILO, 2004; De and Ratha, 2005). Many migrant women seize the opportunity to buy land or real estate with their earnings (e.g. Indian and Filipina migrants). Many tend to remit more of their earnings then men, and to exercise control of their household income by ensuring the remittances are spent on food and clothes for the family back home (IOM, 2005b). This general pattern has been observed elsewhere, despite the fact that women often do not have the same labour opportunities abroad and tend to earn less than men (ILO, 2004). Increased education seems to encourage more migration of women (UNESCAP, 2003a), and in turn foster greater education of females. For Indonesian women in the Gulf Countries, migration can be both a way of seeing the world and making a pilgrimage to Mecca (ILO, 2004).

For many poor women, migration has strengthened their agency within structures that normally offer them few opportunities. And lesser paid, lesser regarded occupations like domestic work or sex work have enabled them to carve out spaces for control and influence at home and in the community. In Kerala, India, in the 1990s, the so-called "gulf wives" left behind by male emigrants were found to experience loneliness and too high a work burden at home. But today, they and their daughters form a new generation of self-confident, independent female managers in Kerala (UNESCAP, 2003a).

Migration increasingly offers women education and career opportunities that may not be available, or be denied them, at home, as well as alternatives to marriage, the traditional role of home carer (even though it is often home care that the women engage in abroad) and some of the more negative cultural practices regarding women 
(such as genital cutting). These opportunities include domestic work in other households for an income rather than to be an unpaid domestic in their own household (Momsen, 1999).

Migration as a transforming experience can improve or worsen the position of women in families and society. It can also do that for men, but often not in a way that is as gender- specific. It is important to note that while statistics under-represent the number of females who migrate, they tell us even less about the number who ultimately ends up in the workforce, regardless of how they migrated (Carling, 2005).

\section{Results and Discussion}

The study found that the main reason for their poverty situation is low income regarding the lack of educational attainment of the women (73\%) have negatively affected their present living standard. And also most of the women (14\%) reported that present poverty alleviation program (Samurdhi) isn't enough to overcome the poverty situation. Other reasons for women's migration were image the relationship of present poverty situation in the area (6\%), lost some valuable opportunities for their education due to poor condition of their families (12\%), thinking much about their children and fulfill their requirements than others requirements of the households' (54\%) etc. It seems that there is no good guidance for the poor people of the area. As many of the people in the village have the negative ideas about their poverty situation, there should be stronger guidance for the people.

Remittances are one of the most visible developmental effects of migration, although too little is still known about their impact on poverty. There is evidence that they alleviate poverty at the household level in some countries, among others by funding child schooling, reducing child labour, increasing family health and expanding durable good ownership (Yang, 2004). According to the G8, remittances by both male and female migrants have become the most stable source of foreign assistance for their home countries (Ramirez et al, 2005). They form a "family welfare system", which can help smooth consumption, alleviate liquidity constraints and provide a form of mutual insurance. As such, they particularly affect women, as traditional homemakers and major recipients of remittances, but also increasingly as heads of households in place of the migrating men (Sander and Maimbo, 2003).

While there is evidence that remittance flows and expenditure patterns can be highly gender- specific, there is still too little research on the relationship between gender and remittances. Most of it is piecemeal and scattered throughout general studies on remittances. Most household surveys do not account for gender differences, and most data collected on remittances do not disaggregate by sex. There is particularly little on how the culturally constructed roles that men and women play in their home countries can influence the way in which they invest their remittances.

It is clear that low-middle income regions with a high share of female emigration, such as Latin America and the Caribbean, or South Asia, also have high remittance rates (LAC $=35 \%$ of all remittances globally in 2003). This is true also of female dominated sectors, such as the domestic worker sector in Kuwait. And there is some evidence that females tend to remit more of their earnings than men. The domestic workers in Kuwait were found by ILO to remit a higher percentage of their income monthly (more than $85 \%$ ) than the men $(78.5 \%)$ (ILO, 2004).According to the household survey showed that some 55\% of the more than 50 lacksfamilies benefiting from remittances are female. This is ascribed to the culturally-based domesticated roles assigned women in the survey. In parts of Asia, it is common for the mother or other female relative of a remitting female migrant to both care for the family in the absence of the migrant, and to receive and spend the remittances, often on instruction from the migrant (Momsen, 1999).

Analyses by the World Bank and others tell us that remittances sent and/or received by females can have a positive effect on health, education and mortality of children. In some countries, women tend to remit a higher 
percentage of their salaries than men (although overall less than men, because of low salary levels), and prioritize nutrition, health and education for the family over savings and investments for the future (Escriva and Ribas, 2004). These priorities are mirrored in the behaviour of female heads of households receiving the remittances in the country of origin. It is understandable that migrant women are generally successful in improving the economic situation of their families although little more than a quarter of the migrant families reported that monthly household income was sufficient after migration. More than three quarters (75 per cent) reported that the household income increased due to the migration of women (Table5.1)

Table 5.1 Household opinion of whether the household income increased due to migration

\begin{tabular}{|l|l|}
\hline & \\
Income increase & Total \\
\hline High increase & \\
\hline Moderate increase & $10 \%$ \\
\hline Increase & $25 \%$ \\
\hline No increase at all & $30 \%$ \\
\hline Total & $10 \%$ \\
\hline
\end{tabular}

Source: Field Study, 2017

Regression analysis based on a recent survey conducted in Sri Lanka by the World Bank shows that remittances received by female heads of household in Sri Lanka have a positive impact on health and education of the children (controlling for sex, age, land ownership, food consumption, absence of father etc) (De and Ratha, 2005). Feedback to a question in this survey about the ownership of major items such as housing, land, and vehicles and consumer durables before migration and after migration are shown in Table 5.2. By comparison, in Sri Lanka it was found that where males are heads of households, there is rather a more positive impact on asset accumulation. An analysis of the impact of exchange rates on Filipino remittances and a range of household outcomes in the Philippines finds that positive exchange rate shocks generally result in higher household expenditure on education for children, but with a higher increase in education for girls (Yang, 2004)).

Table 5.2Ownership of major items before and after migration

\begin{tabular}{|c|c|c|c|c|c|c|c|c|}
\hline \multirow[t]{2}{*}{ Ownership } & \multicolumn{8}{|c|}{ Percentage } \\
\hline & 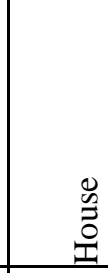 & ت્己 & $\begin{array}{l}\frac{0}{0} \\
\frac{0}{0} \\
\end{array}$ & 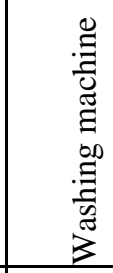 & 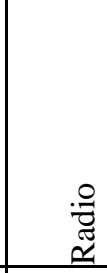 & 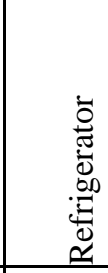 & 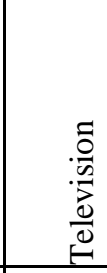 & 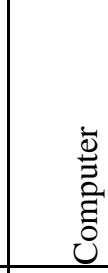 \\
\hline $\begin{array}{l}\text { Had before migration } \\
\text { and no improvement }\end{array}$ & $40 \%$ & \multirow[b]{2}{*}{$70 \%$} & & & $50 \%$ & $10 \%$ & $20 \%$ & $0.0 \%$ \\
\hline $\begin{array}{l}\text { Had before migration } \\
\text { but now improved }\end{array}$ & $30 \%$ & & $10 \%$ & $10 \%$ & $20 \%$ & $10 \%$ & $10 \%$ & $0.0 \%$ \\
\hline
\end{tabular}




\begin{tabular}{|l|l|l|l|l|l|l|l|l|}
\hline Had after migration & $20 \%$ & $20 \%$ & $10 \%$ & $30 \%$ & $20 \%$ & $20 \%$ & $50 \%$ & $10 \%$ \\
\hline Do not still own & $10 \%$ & $10 \%$ & $80 \%$ & $70 \%$ & $10 \%$ & $60 \%$ & $20 \%$ & $90 \%$ \\
\hline Total & $100 \%$ & $100 \%$ & $100 \%$ & $100 \%$ & $100 \%$ & $100 \%$ & $100 \%$ & $100 \%$ \\
& $\mathrm{~N}=80$ & $\mathrm{~N}=80$ & $\mathrm{~N}=80$ & $\mathrm{~N}=80$ & $\mathrm{~N}=80$ & $\mathrm{~N}=80$ & $\mathrm{~N}=80$ & $\mathrm{~N}=80$ \\
\hline
\end{tabular}

Source: Field Study, 2017

In this research, it is shown that the overall increased income through remittances improves children's health and mortality rates $(62 \%)$. This is in addition to the general improvement of family health through the increased health education of female migrants abroad. Furthermore the study has found that children of migrant households are estimated to be 1-2 percent less likely to die in their first year than children born in households without a migrant member.

The impacts of poverty and migration on health - of the migrants, their families, and the public - are complex and vary according to a large number of factors, including public policy, culture, vulnerability of mobile populations and sexual behaviour, all of which can be highly gender- specific. There continue to be enormous disparities in health between developed and developing countries, or poorer and richer regions within countries; and poverty is the critical indicator for these. Public policies can play a critical role in correcting this, but there is as yet insufficient connection between migration, health and development policy-making, despite the globalized impacts and costs of such pandemics as AIDS.

Government policies can be crucial for stimulating productive use of remittances, but in some developing countries of origin the legal systems limit or even exclude women from owning land or accessing the means to gain credit or loans and invest remittances more productively (Ramirez et al, 2005). Migrant workers' earnings are also spent in investments and on savings (Kageyama 2008). Of the total migrant families in the study, 70 per cent reported that they invested migrants' earnings in both productive and non-productive items. These productive investments include land and setting up a business and non-productive activities includes housing, vehicle and household items. About80percenthadtheopinionthattheirsavingsof migrant's remittances were sufficient (Table 5.18). Little more than a third reported that the money they saved was enough and only one respondent said that their savings are more than enough.

Table 5.18 Respondent opinion about the adequacy of their savings

\begin{tabular}{|l|l|l|}
\hline Opinion about savings & Number & Percentage \\
\hline More than enough & 1 & $5 \%$ \\
\hline Enough & 3 & $15 \%$ \\
\hline Not enough & 16 & $80 \%$ \\
\hline Total & 20 & $100 \%$ \\
\hline
\end{tabular}

Source: Field Study, 2017

The extent to which destination countries support the settlement and integration of migrants in the host community can influence their propensity to remit funds, indeed generally to contribute through knowledge exchange or other "returns" to the home country. There is still inconclusive evidence to show that greater settlement in the destination country will lead to more or fewer remittances and ties with the origin country. Some studies show that women have a greater tendency to settle in the destination country, and initiate family 
unification, thereby reducing future remittances home (Ramirez, 2005). But there are too few examples, and there is still inadequate evidence that long term migration or settlement generally leads to lowered remittance flows (World Bank, 2005 (forthcoming)).

Remittances have been able to strengthen women's economic status in both countries of origin and destination, and in some cases help them to re-negotiate the gender roles at home. Women send money home, and in many cases it is other women in the family who receive and use the remittances for the family. In this study found that left behind by women (78\%) worked in the abroad feel that their status and authority have increased through remittances. By last few years, half of them had houses or land in their own names, some 40 percent had their own income, which they controlled, and 7 out of 10 kept their own bank accounts.

Thus, women back home have also been able to strengthen their role as financial managers, in some instances through creative investments $(67 \%)$ like microcredit enterprises. This is seen as a new form of transnational networking at the household level, with multiplier effects at the societal level, even if only symbolic.

\section{Conclusion}

These migrant women come from low-income families and have lower levels of education, which lives their possibilities of entering into the local labour market. Even if they are employed in Sri Lanka, their salaries are low, and also their families live in poverty. They need money to improve the economic and social well-being of their family members. Since they find no other options to earn money in Sri Lanka, they take the decision to migrate. In addition, the reason for their migration is mainly economic. These economic reasons contain poverty, limited employment opportunities for them to work in Sri Lanka, unavailability of permanent jobs for their husbands, repayment of debts, buying a land, building a house, and family obligations. Poverty alleviation and building a house were reported as the basic reasons for migration by an equal proportion of migrant families. Non-economic reasons like as providing better education and health for their children and recovering husband's illness were reported as main reasons only by a small proportion of families. Insufficient household income to fulfill their needs is a major problem of these migrant families. One of the facts that the migrant women tended to come from poorer families is also reflected in the nature of occupation of the migrants' husbands. Sri Lankan migrant women have lower levels of education which is only primary education. Their lower levels of education can have a heavy impact on their salaries, money management, and communicating with their employers.

The most direct benefit from migration is the incensement in the household income. It is reflected in the findings of the rise in the average monthly income of the households, increase in the adequacy of household income, and the increase in migrants' income. Migrant families had a low average monthly household income at the time of their migration. With the migration of women, the average monthly income of the households has increased. Consequently, the proportion of the families whose monthly income was sufficient to meet their family needs has also risen significantly.

A positive relationship is reported between the percentages of families who reported that their monthly income was sufficient as a result of the migration of women and the duration of work abroad. This finding suggests that migrant women can get more economic benefits in relation to the increase in household income only if they can work more years overseas. Migration has supported in the ability of women to contribute to the daily expenses of the household.

It is apparent that migrant women are generally successful in developing the economic situation of their family since there is an increase in the household income. There had been a high or impartial increase in income for about one third of the households. This increase is significant as the duration of work overseas increases. Their remittances not only supported to increase the household income, but also enhanced the ability to purchase and improve family housing and land ownership, and to purchase or upgrade household consumer durables. This 
suggests that remittances minimize poverty and improve access to goods and services, thereby extending opportunities for people to improve their living standards.

Almost all migrant families sent their portion salary to their families or a bank account in Sri Lanka. Migrant's husbands were the main recipient of remittances. Parents also receive remittances from migrants because they play a key role in financial activities of the households. Migration of women is closely related to their family needs, in particular to improve the living conditions of their families. These families used these remittances for children's education, children's health, and repaying debts. A considerable proportion of these families were able invest for productive and non-productive items. An investment in non-productive items such as housing is higher than productive items such as land and setting up a business. Moreover, little number of these families was able save some money. Likewise finally those findings helps to prove women's migration directly give major benefits especially from remittances to reduce the poverty situation of their families.

\section{Reference}

Adams, R., 2004, "Remittances and poverty in Guatemala", World Bank Policy Research Working Paper 3418, September. 2005, "Remittances and Poverty in Ghana", World Bank Policy Research Working Paper (in draft), Washington D.C.

Adams, R and J Page, 2005, "Do International Migration and Remittances Reduce Poverty in Developing Countries?" (Revised April 21), World Bank, forthcoming Fall 2005.

Addis Ababa University, 2000, "Migration, Gender and Health Survey in Five Regions of Ethiopia: 1998", Demographic Training and Research Center, Institute of Development Research, Addis Ababa, Ethiopia, July 2000.

Carling, J., 2005, "Migrant Remittances and Development Cooperation", PRIO Report 1/2005, International Peace Research Institute, Oslo.

DE, P. and D. Ratha, 2005, "Remittance income and household welfare: evidence from Sri Lanka Integrated Household Survey", World Bank, mimeo.

Martin, S, 2004, "Women and Migration", prepared for the UN Division for the Advancement of Women (DAW) Consultative Meeting on Migration and Mobility and How this Movement Affects Women, 2-4 December, Sweden.

Memon, R, 2005, "Pakistan: Internal Migration and Poverty Reduction", in Migration, Development and Poverty reduction in Asia, proceedings of the Regional Conference on Migration and Development in Asia, Lanzhou, China, sponsored by the UK Department for International Development, IOM, Geneva.

UNGA (UN General Assembly), 2004, "World Survey on the role of women in development", Report of the Secretary General, addendum on "Women and international migration", September, New York. 